九州大学学術情報リポジトリ

Kyushu University Institutional Repository

\title{
Characterization of Mungbean (Vigna radiata (L. ) Wilczek) Genotypes for Yield and Yield Components
}

Is Lam, Muhammad Tajul

Laboratory of Practical Botany, Faculty of Agriculture, Kyushu University

Agata, Waichi

Laboratory of Practical Botany, Faculty of Agriculture, Kyushu University

Kubota, Fumitake

Laboratory of Practical Botany, Faculty of Agriculture, Kyushu University

https://doi.org/10.5109/24040

出版情報: 九州大学大学院農学研究院紀要. 38 (1/2)，pp.81-88，1993-12. Kyushu University バージョン：

権利関係 : 


\title{
Characterization of Mungbean (Vigna radiata (L.) W ilczek) Genotypes for Yield and $\mathrm{Y}$ ield Components
}

\author{
Muhammad Tajul Islam, Waichi Agata and Fumitake Kubota \\ Laboratory of Practical Botany, Faculty of Agriculture, Kyushu \\ University, 46-01, Fukuoka 812, Japan. \\ (Received July 20, 1993)
}

\begin{abstract}
Seventy seven mungbean genotypes collected from different Asian countries were evaluated on yield and yield components in relation to phenological characteristics. Growth period of the genotypes ranged from 61 to 87 days. Based on the days to maturity, the genotypes were grouped into early, medium and late. Flowering period was between 29 to 38 days. Mean air temperature during the growth period of the genotypes was around 24 to $25^{\circ} \mathrm{C}$. The cumulative air temperature ranged from 1481 to $2210^{\circ} \mathrm{C}$. The solar radiation was between 12 to $13 \mathrm{MJ} / \mathrm{m}^{2}$. There were large variations among the genotypes for seed yield per plant $(5.3 \mathrm{~g}$ to $29.9 \mathrm{~g})$. Seed yield had a close significant relationship with seeds per plant than 100 -seed weight. Seeds per plant related more closely to pods per plant than seeds per pod. Other yield components without seeds per plant and pods per plant were not significantly associated with yield. 100-seed weight had negative significant relationship with seeds per plant and pods per plant. Seeds per plant and pods per plant had significant relationship with plant height and number of main branch per plant. Harvest index (HI) was also significantly related with yield. Therefore, it is considered that selection of genotypes with higher pods per plant, higher seeds per plant and higher $\mathrm{HI}$ is effective for breeding of high yielding genotypes.

It is clear from the growth status in this experiment that, this crop can be successfully cultivated in the West-Southern part of Japan during summer.
\end{abstract}

\section{INTRODUCTION}

Mungbean contains 3 times more high quality protein than the cereals. The crop is tropical to sub-tropical in nature and can be successfully grown between $25-30^{\circ} \mathrm{C}$. It can sustain under $40^{\circ} \mathrm{C}$; but the seeds do not germinate or the growth is stunted below $20^{\circ} \mathrm{C}$ of day and night temperature.

Mungbean shows highly flexible performance depending on the location of growing. As a result, the yield and other morphophysiological traits of the same genotypes become highly unpredictable. Results from International Mungbean Nursery Yield Trials indicate that the major factors influencing mungbean yield is in the order of environment(E) > genotype $(\mathrm{G})>(\mathrm{E}) X(\mathrm{G})$ interaction and out of these factors environment only contributes 60-80\% (Imrie et al., 1981; Imrie and Shanmugasundaram, 1987). In the tropical and sub-tropical regions, mungbean is highly infested with yellow mosaic virus. Therefore, the field evaluation of the genotypes seems to be disturbed. In Japan, during the growth period we did not find any incidence of viral disease. Therefore, evaluation of genotypes in a disease free environment as in Japan seems to be highly effective to get potentiality of the genotype.

Mungbean is not grown as a commercial crop in Japan and hence remains as an unknown crop to most of the people. But adzuki bean which belongs to the same genus 
as that of mungbean, is widely cultivated all over Japan. Till now, sporadic attempts (Trung and Yoshida, 1982; Trung and Yoshida 1985; Francisco and Maeda, 1989a; Francisco and Maeda 1989b; Hamid et al., 1990) have been made to carry out some research on mungbean, but none of them were on the characterization of the yield and yield components of the crop which is the ultimate goal of improvement. So, this study was undertaken to characterize different mungbean genotypes under the same environmental conditions.

\section{MATERIALS AND METHODS}

The 77 genotypes used in this study were collected from 10 different countries (Bangladesh, Taiwan, India, Pakistan, Philippines, Nepal, Thailand, Indonesia, Srilanka and China) of Asia. Plants were grown in $8 \mathrm{~L}$ pots (one plant/pot) on May 24, 1991. There were 3 replications per genotype. Sandy loam soil mixed with $5 \mathrm{~g}$ of compound chemical fertilizer ( $N: P: K=16: 16: 16$ ) were used in each pot. Five pre-germinated seeds were sown in order to get uniform plant stand. At two leaf stage of the plant, thinning of the seedlings was done to keep one plant per pot. Watering and mulching was done as and when necessary. Phenological characteristics such as date of flowering, plant height, date of maturity were recorded for each genotype. Also, yield and yield components such as yield per plant, number of seeds per plant, 100-seed weight, number of seeds per pod, number of pods per plant, pod length, were recorded at harvest of the crop. Harvest index (HI) was calculated by the formula:

$$
\text { Harvest index }(\%)=\frac{\text { Economic yield }}{\text { Biological yield }} \times 100
$$

The grouping on yield and yield components of the genotypes were done based on "Mean \pm Standard deviation".

Climatic data were obtained from the Fukuoka Meteorological Station, Fukuoka.

\section{RESULTS}

In all the genotypes, the germination was uniform and all the genotypes had completed their growth cycle including the production of harvestable seeds. However, there were large variations in days to flower and days to maturity among the genotypes (Table 1). The number of days to flower ranged from 29 to 38 days after emergence. Only 4 (E 6, E 22, P 127 and 7703) genotypes (5.2\% of the total) among those flowered the earliest (29 DAE). About $36.4 \%$ of the total genotypes had flowered between 33 and 34 days after emergence. As to the number of days to maturity, similar trend among the genotypes was recognized. It ranged from 61-87 days. From the results, ten genotypes (13.0\%) were identified as early maturing genotypes; while, $16.0 \%$ of the genotypes were grouped as late maturing genotypes. The genotype 880138 was harvested at the earliest (61 days after emergence) and genotype 880032 was harvested as the last one at 87 days after emergence. Among the genotypes $50.6 \%$ were harvested between 71 to 75 days after emergence. The mean air temperature for days to flower 
Table 1. Mean and cumulative air temperatures and mean solar radiation for days to flower and maturity of mungbean genotypes.

\begin{tabular}{|c|c|c|c|c|c|c|c|c|c|}
\hline \multicolumn{5}{|c|}{ Days of flower } & \multicolumn{5}{|c|}{ Days to maturity } \\
\hline $\mathrm{C}$ & $\mathrm{F}$ & $\begin{array}{c}\text { Temp. }{ }^{\circ} \mathrm{C} \\
\text { (mean) }\end{array}$ & $\begin{array}{l}\text { Temp. }{ }^{\circ} \mathrm{C} \\
\text { (cumulative) }\end{array}$ & $\begin{array}{l}\text { Mean solar } \\
\operatorname{rad}\left(\mathrm{M} \mathrm{J} / \mathrm{m}^{2}\right)\end{array}$ & $\mathrm{C}$ & $\mathrm{F}$ & $\begin{array}{c}\text { Temp. } \\
\text { (mean) }\end{array}$ & $\begin{array}{l}\text { Temp. }{ }^{\circ} \mathrm{C} \\
\text { (cumulative) }\end{array}$ & $\begin{array}{l}\text { Mean solar } \\
\operatorname{rad}\left(\mathrm{MJ} / \mathrm{m}^{2}\right)\end{array}$ \\
\hline $29-30$ & 4 & 22.1 & $641.8-663.9$ & 12.2 & $61-65$ & 14 & 24.5 & $1481.3-1599.1$ & 12.9 \\
\hline $31-32$ & 8 & 22.1 & $685.6-708.0$ & 12.0 & $66-70$ & 10 & 24.8 & $1628.8-1744.7$ & 13.3 \\
\hline $33-34$ & 29 & 22.2 & $729.8-758.2$ & 12.1 & $71-75$ & 39 & 25.0 & $1774.7-1876.1$ & 13.3 \\
\hline $35-36$ & 21 & 22.5 & $780.4 \quad-812.3$ & 12.2 & $76-80$ & 12 & 25.0 & $1899.9-2000.3$ & 13.5 \\
\hline $37-38$ & 15 & 22.7 & $839.5-864.4$ & 12.0 & $81-85$ & 1 & 25.0 & $2052.1-2182.8$ & 13.6 \\
\hline & & . & & & $86-90$ & 1 & 25.1 & $2155.6-2209.8$ & 13.8 \\
\hline
\end{tabular}

C, Class (days) ; F, Frequency (number of genotypes).

Table 2. Frequency distribution of total dry weight (TDW), plant growth rate (PGR), seed yield per plant and harvest index (HI) of mungbean genotypes.

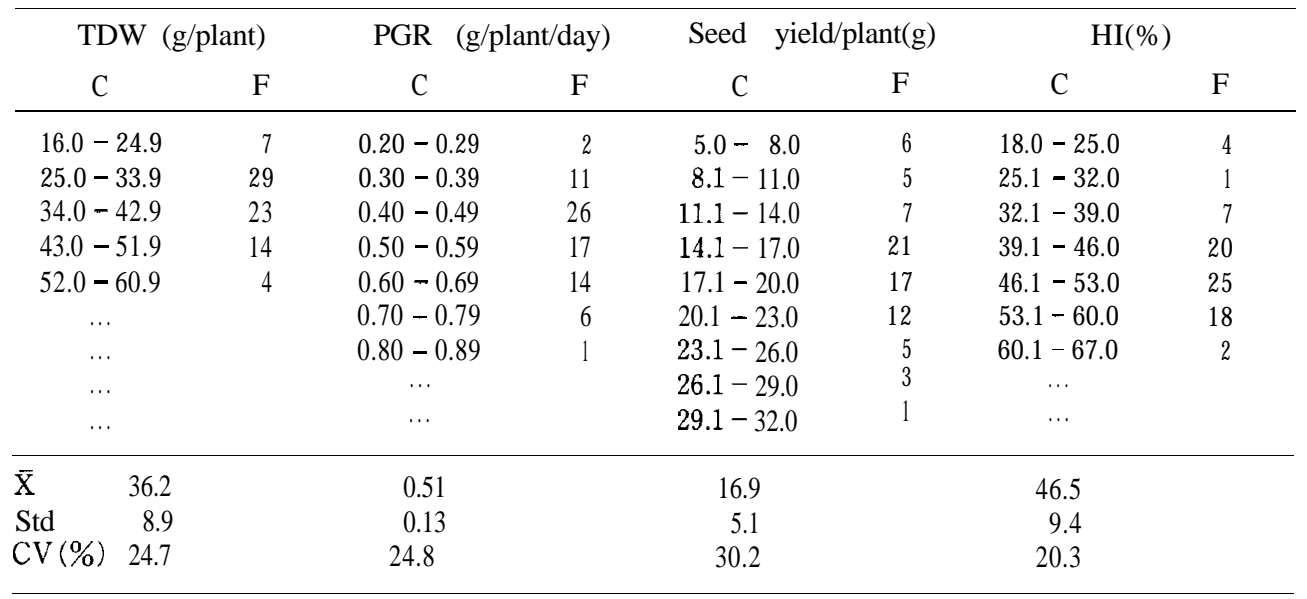

C, Class; F, Frequency (number of genotypes); $\overline{\mathrm{X}}$, Mean; Std, Standard deviation; CV, Coefficient of variation.

did not vary widely and was around $22^{\circ} \mathrm{C}$; for days to maturity it was between 24 to 25 "C. The cumulative air temperature for total growth period varied largely. Eighteen percent of the genotypes had cumulative air temperature between $1481-1599.1^{\circ} \mathrm{C}$ and 1.3\% had 2155.6 - 2209.8 "C. Most of the genotypes (50.6\%) had cumulative air temperature between $1774.7-1876.1^{\circ} \mathrm{C}$. Mean solar radiation did not vary to a large extent for both days to flower and days to maturity and it was between 12 to $14 \mathrm{MJ} / \mathrm{m}^{2}$ (Table 1).

Table 2 elucidates the range of growth and seed yield of the genotypes evaluated. Total dry weight (TDW) ranged from 17.0 to $58.2 \mathrm{~g} / \mathrm{plant}$. Most of the genotypes concentrated in the range of 25 to 34 . Plant growth rate (PGR) ranged from 0.27 to $0.86 \mathrm{~g} / \mathrm{plant} / \mathrm{day}$. Yield per plant ranged from a minimum of $5.3 \mathrm{~g}$ to maximum $29.9 \mathrm{~g}$. 
Table 3. Frequency distribution of yield components of mungbean genotypes

\begin{tabular}{|c|c|c|c|c|c|c|c|c|c|c|c|c|c|}
\hline \multicolumn{2}{|c|}{$\begin{array}{c}\text { No. of Seeds } \\
\text { per plant }\end{array}$} & \multicolumn{2}{|c|}{$\begin{array}{r}100-\text { seed } \\
\text { weight }(\mathrm{g})\end{array}$} & \multicolumn{2}{|c|}{$\begin{array}{c}\text { No. of seeds } \\
\text { per pod }\end{array}$} & \multicolumn{2}{|c|}{$\begin{array}{l}\text { No. of pods } \\
\text { per plant }\end{array}$} & \multicolumn{2}{|c|}{$\begin{array}{l}\text { Pod length } \\
\quad(\mathrm{cm})\end{array}$} & \multicolumn{2}{|c|}{$\begin{array}{l}\text { No. of main } \\
\text { branch }\end{array}$} & \multicolumn{2}{|c|}{$\begin{array}{c}\text { Plant height } \\
(\mathrm{cm})\end{array}$} \\
\hline $\mathrm{C}$ & $\mathrm{F}$ & $\mathrm{C}$ & $\mathrm{F}$ & $\mathrm{C}$ & $\mathrm{F}$ & $\mathrm{C}$ & $\mathrm{F}$ & $\mathrm{C}$ & $\mathrm{F}$ & $\mathrm{C}$ & $\mathrm{F}$ & $\mathrm{C}$ & $\mathrm{F}$ \\
\hline $101-200$ & 7 & $2.0-3.0$ & 7 & $7.1-9.0$ & 3 & $11.0-20.0$ & 9 & $5.1-6.0$ & 3 & $1.0-2.0$ & 1 & $\begin{array}{ll}35.0 & -40.0\end{array}$ & 5 \\
\hline $201-300$ & 14 & $3.1-4.0$ & 34 & $9.1-11.0$ & 35 & $20.1-30.0$ & 20 & $6.1-7.0$ & 28 & $2.1-3.0$ & 17 & $40.1-45.0$ & 14 \\
\hline $301-400$ & 18 & $4.1-5.0$ & 7 & $11.1-13.0$ & 37 & $30.1-40.0$ & 11 & $7.1-8.0$ & 16 & $3.1-4.0$ & 38 & $45.1 \quad-50.0$ & 21 \\
\hline $401-500$ & 6 & $5.1-6.0$ & 6 & $13.1-15.0$ & 1 & $40.1-50.0$ & 8 & $8.1-9.0$ & 7 & $4.1-5.0$ & 19 & $50.1 \quad-55.0$ & 15 \\
\hline $501-600$ & 10 & $6.1-7.0$ & 9 & $15.1-17.0$ & 1 & $50.1-60.0$ & 18 & $\begin{array}{ll}9.1 & -10.0\end{array}$ & 10 & $5.1-6.0$ & 1 & $55.1-60.0$ & 13 \\
\hline $601-700$ & 12 & $7.1-8.0$ & 9 & $\cdots$ & & $\begin{array}{ll}60.1 & -70.0\end{array}$ & 11 & $10.1-11.0$ & 9 & $6.1-7.0$ & 1 & $60.1-65.0$ & 7 \\
\hline $701-800$ & 8 & $8.1-9.0$ & 4 & $\cdots$ & & $\ldots$ & & $\ldots$ & & $\ldots$ & & $65.1-70.0$ & 2 \\
\hline $801-900$ & 2 & $9.1-10.0$ & 1 & $\cdots$ & & $\ldots$ & & $\ldots$ & & $\ldots$ & & $\cdots$ & \\
\hline$\beta$ & 451.2 & & 10 & 11.1 & & 40.4 & & 7.9 & & 3.8 & & 52.4 & \\
\hline Std & 198.7 & & 8 & 1.3 & & 16.6 & & 1.5 & & 0.8 & & 8.3 & \\
\hline $\mathrm{CV}(\%)$ & 44.0 & & & 11.8 & & 41.1 & & 18.3 & & 21.8 & & 15.9 & \\
\hline
\end{tabular}

C, Class; F, Frequency (number of genotypes); $\overline{\mathrm{X}}$, Mean; Std, Standard deviation; CV, Coefficient of variation.

The number of genotypes in the lowest yield class $(5-8 \mathrm{~g})$ was $10.4 \%$ of the total; and only one genotype $(1.3 \%)$ was in the highest yield group. Harvest index ranged from $18.5 \%$ to $65.2 \%$. About $30 \%$ of the genotypes had harvest index between 46.1 to $53.0 \%$.

Table 3 represents frequency distribution, mean, standard deviation and coefficient of variation of some of the yield components of mungbean. For 100-seed weight, number of the genotypes in the smallest seeds group was 7, which was $9.0 \%$ of the total. Most of genotypes $(44.0 \%)$ were in the range of $3.1-4.0 \mathrm{~g}$. About $26.0 \%$ of the genotypes had 30.1 to 40.0 pods per plant and $23.3 \%$ of the genotypes had 50.1 to 60.0 pods per plant.

The correlation coefficients shown in table 4 are, among the growth, environmental conditions and seed yield. TDW had positively significant relationship with PGR and seed yield. Mean temperature, cumulative temperature and mean solar radiation had significant relationship with days to flower and days to maturity. Harvest index (HI) had significant correlation with only seed yield, seeds per plant and pods per plant. It indicates that HI together with TDW (Table 4) is important for yield production of mungbean.

Table 5 shows relationships between seed yield and yield contributing characters. Yield components in mungbean are primarily seeds per plant, seed weight, pods plant and seeds per pod. Seed yield had related more to seeds per plant than 100 -seed weight. The seeds per plant related more closely to pods per plant and seeds per pod. Other yield components, without seeds per plant and pods per plant were not significantly associated with yield. Furthermore, pods per plant and seeds per plant had significant relationships with plant height and number of main branch per plant. Also there was a low correlation between seed yield and plant height. On the other hand, seeds per plant had a negative relationship with 100-seed weight and pod length. Similarly, 100-seed weight had a negative significant relationship with pods per plant. 
Table 4. Correlation coefficient among growth, environmental factors and seed yield of mungbean genotypes.

\begin{tabular}{|c|c|c|c|c|c|c|c|c|}
\hline \multirow[b]{2}{*}{ TDW } & \multirow{2}{*}{$\begin{array}{l}\text { PGR } \\
0.947^{* * *}\end{array}$} & \multicolumn{2}{|c|}{ Seed yied $\mathrm{HI}$} & \multicolumn{3}{|c|}{ Days to Days to Mean solar } & $\begin{array}{l}\text { Mean } \\
\text { perature tes }\end{array}$ & $\begin{array}{l}\text { Cumulative } \\
\text { emperature }\end{array}$ \\
\hline & & $0.731^{* * *}$ & $-0.041^{\mathrm{nE}}$ & $0.269^{* *}$ & $0.179^{\prime}$ & $" 0.164^{\mathrm{rs}}$ & $0.135^{\text {r }}$ & $0.178^{\mathrm{IB}}$ \\
\hline PGR & & $0.697^{* * *}$ & $-0.034^{\mathrm{ns}}$ & $0.192^{\mathrm{rs}}$ & $-0.137^{\mathrm{ns}}$ & $-0.123^{\text {ז }}$ & $-0.160^{\text {的 }}$ & $-0.137^{\mathrm{rE}}$ \\
\hline Seed yield & & & $0.629^{* * *}$ & $0.140^{18}$ & $0.141^{\mathrm{ns}}$ & $0.093^{\mathrm{rs}}$ & $0.079 ”$ & $0.135^{\text {rs }}$ \\
\hline $\mathrm{H} \quad \mathrm{I}$ & & & & $-0.091^{\text {IB }}$ & $0.012^{\mathrm{ns}}$ & -0.018 & $-0.008^{\mathrm{rs}}$ & $0.008 "$ \\
\hline Days to flower & & & & & $0.234^{*}$ & $0.273^{*}$ & $0.277^{*}$ & $0.251^{\prime}$ \\
\hline Days to maturity & & & & & & $0.909^{* * *}$ & $0.933^{* * *}$ & $0.998^{* * *}$ \\
\hline Mean solar radiation & & & & & & & $0.973^{* * * *}$ & $0.925^{* * *}$ \\
\hline Mean temperature & & & & & & & & $0.948^{* * *}$ \\
\hline
\end{tabular}

${ }^{*}, * *,{ }^{* *}$, ns represents significant at $5 \%, 1 \%, 0.1 \%$ levels and not significant, respectively.

Table 5. Correlation coefficients among the yield and yield contributing characters

\begin{tabular}{|c|c|c|c|c|c|c|c|c|}
\hline & Seeds/plar & $\begin{array}{l}\text { nt } 100 \cdot \text { seec } \\
\text { weight }\end{array}$ & Seeds/po & d Pods/pla & lant Pod len & $\begin{array}{l}\text { gth No. of } \\
\text { branch }\end{array}$ & $\begin{array}{l}\text { main Plant } \\
\text { height }\end{array}$ & $\begin{array}{l}\text { Harvest } \\
\text { index }\end{array}$ \\
\hline Yield/plant & $0.641^{* * *}$ & $-0.141^{\text {tis }}$ & $0.102 ”$ & $0.659^{* * *}$ & $0.063 ”$ & $0.276^{*}$ & $0.319^{* *}$ & $0.631^{* * *}$ \\
\hline Seeds/plant & & $-0.674^{* * *}$ & $0.414^{* * *}$ & $0.954^{* * *}$ & $-0.553^{* * *}$ & $0.372^{* * *}$ & $0.433^{* * *}$ & $0.331^{* *}$ \\
\hline $100 \cdot$ seed weight & & & $0.263^{*}$ & $-0.650^{* * *}$ & $0.810^{* * *}$ & $0.302^{* *}$ & $0.338^{* *}$ & $0.010^{\text {г }}$ \\
\hline Seeds/pod & & & & $0.135 "$ & $-0.012^{\text {г }}$ & $0.112 ”$ & $0.154 ”$ & $0.016^{\text {rs }}$ \\
\hline Pods/plant & & & & & $0.614^{* * *}$ & $0.425^{* * *}$ & $0.426^{* * *}$ & $0.352^{* *}$ \\
\hline Pod length & & & & & & $0.321^{* *}$ & $0.321^{* *}$ & $0.109 "$ \\
\hline No. of main branch & & & & & & & $0.342^{* *}$ & $0.147 ”$ \\
\hline Plant height & & & & & & & & $0.139^{\mathrm{ns}}$ \\
\hline
\end{tabular}

${ }^{*}, * *,{ }^{* *}$, ns represents significant at $5 \%, 1 \%, 0.1 \%$ levels and not significant, respectively.

About $70.1 \%$ of the genotypes evaluated, were in the medium group for yield and yield components (Table 6). Only $15.6 \%$ of the total genotypes were in the high seed yield group; while $14.3 \%$ were in low group for the same parameter. The early maturing $(<66$ days) genotypes were $19.5 \%$ and late maturing $(>76$ days $)$ genotypes were 14.3\%. The mean values in table 6 shows that, the yield and yield components in high group were three times more compared to the low group. Table 7 shows the genotypes which are grouped into high, low and medium for seed yield per plant.

\section{DISCUSSION}

Solar radiation and temperature are among the most important factors influencing the productivity of the crop. Solar radiation supplies the light energy for the photosynthetic process, modulates the temperature, affects respiration and water loss, and determines the photoperiod. The solar radiation during the summer in Fukuoka appears to be sufficient enough for the successful production of the crop. Air temperature which influences flowering and maturity of the crop also seems to be favorable during summer for growing mungbean in the West-Southern Japanese 
Table 6. Mean values of high, medium and low groups of mungbean genotypes for seed yield and yield components.

\begin{tabular}{|c|c|c|c|c|c|c|c|c|c|c|c|}
\hline Group & $\begin{array}{l}\text { Yield per } \\
\text { plant } \\
\text { (g) }\end{array}$ & $\begin{array}{l}\text { Seeds } \\
\text { plant } \\
\text { (no.) }\end{array}$ & $\begin{array}{c}\text { per } 100 \text {-seed } \\
\text { weight } \\
\text { (g) }\end{array}$ & $\begin{array}{l}\text { Seeds } \\
\text { pod } \\
(\text { no. })\end{array}$ & $\begin{array}{l}\text { per Pod no./ } \\
\text { plant } \\
\text { (no.) }\end{array}$ & $\begin{array}{l}\text { Pod length } \\
\text { (cm) }\end{array}$ & $\begin{array}{l}\text { No. of } \\
\text { branch } \\
\text { (no.) }\end{array}$ & $\begin{array}{l}\text { Plant I } \\
\text { height } \\
\text { ( }(\mathrm{cm})\end{array}$ & $\begin{array}{l}\text { Days to* } \\
\text { flower }\end{array}$ & $\begin{array}{l}\text { Days to* } \\
\text { maturity }\end{array}$ & $\begin{array}{l}\text { Harvest } \\
\text { index } \\
(\%)\end{array}$ \\
\hline High & 24.99 & 721.54 & 7.55 & 13.28 & 63.77 & 10.05 & 5.19 & 66.68 & 37.8 & 79.18 & 59.71 \\
\hline Low & 8.31 & 190.03 & 2.51 & 9.03 & 19.25 & 6.19 & 2.2 & 40.85 & 30.45 & 62.38 & 27.54 \\
\hline Medium & n 16.99 & 424.53 & 4.12 & 11.12 & 40.11 & 7.47 & 3.77 & 51.85 & 34.48 & 71.94 & 47.48 \\
\hline
\end{tabular}

${ }^{*}$ High $=$ Late

Low $=$ Early

Table 7. Mungbean genotypes grouped into high, medium and low classes based on seed yield per plant.

\begin{tabular}{|c|c|c|c|c|c|}
\hline \multirow{2}{*}{$\begin{array}{r}\text { High } \\
880144\end{array}$} & \multirow{2}{*}{$\begin{array}{c}\text { Low } \\
\text { Mosk } 1\end{array}$} & \multicolumn{4}{|c|}{ Medium } \\
\hline & & VC $3689 A$ & VC $3301 \mathrm{~A}$ & M 99 & VC $2768 \mathrm{~A}$ \\
\hline 88092 & 880137 & 880142 & 880130 & BM-84-1-38-3 & VC $3902 A$ \\
\hline 88070 & BM-84-2-93-2 & 880139 & E 16 & $30 \mathrm{R}(4 * 10)$ & P 114 \\
\hline 880132 & MBCB 1 & VC $4080 \mathrm{~A}$ & 880141 & MBCB 3 & BM-84-2-24-1 \\
\hline 880138 & KPS 2 & 2709 & V 3476 & E 11 & BM-84-2-7-3 \\
\hline E 10 & E 1 & VC $2802 \mathrm{~A}$ & 880146 & VC $2991 \mathrm{~A}$ & VC $2917 \mathrm{~A}$ \\
\hline 880032 & $9(1 * 10) 7$ & VC $1973 \mathrm{~A}$ & E 27 & BM-84-2-7-1 & E 6 \\
\hline Chinese & 7703 & 880140 & $31 \mathrm{R}(5 * 6) 15$ & $24(4 * 7) 5$ & $\mathrm{E} 2$ \\
\hline 880145 & PIMS Viny & $\mathrm{VC} 3300 \mathrm{~A}$ & Mosk 2 & BM-84-1-6-3 & E 19 \\
\hline 7715 & $\mathrm{E} 22$ & 880134 & BM-84-1-60-4 & P 128 & V 3726 \\
\hline Indonesian & P 127 & $32(5 * 4) 12$ & $19 \mathrm{R}(3 * 5) 2$ & Pagasa 2 & VC $4066 \mathrm{~A}$ \\
\hline \multirow[t]{3}{*}{ VC 3741A } & & VC 3737A & Isd local & $\mathrm{VC} 4111 \mathrm{~A}$ & E 8 \\
\hline & & BM-84-2-7-3 & VC $3890 A$ & BM-84-2-14-1 & $\mathrm{VC} 3117 \mathrm{~A}$ \\
\hline & & $36 \mathrm{R}(6 * 7) 1$ & BM-84-2-40-2 & & \\
\hline
\end{tabular}

climate. The mean temperature for successful growth of the crop were $22{ }^{\circ} \mathrm{C}$ for flowering and $24-25^{\circ} \mathrm{C}$ for maturity. Also cumulative temperature for flowering ranged from $642-864^{\circ} \mathrm{C}$ and for maturity it ranged from $1481-2210^{\circ} \mathrm{C}$. From the last 50 years observation, it is found that these temperature regimes prevail in Fukuoka during summer from June to September.

PGR is an indication of the conversion efficiency of photosynthesis. There were few genotypes with high PGR and these may be promising genotypes for the improvement of the crop. Significant relationship of TDW and PGR to seed yield indicates that breeding for increase in TDW and PGR may lead to increase in yield of mungbean. Temperature affects the length of the vegetative growth phase and the initiation of flowering. Increase in mean temperature during the vegetative phase hastens flowering (Aggarwal and Phoelman, 1977). Higher air temperature incite flower shading, particularly if there is lack of soil moisture and low humidity. In this study, the low significant relationship between days to flower and mean temperature and solar 
radiation may be because of the little genetic variation for this parameter. But on the other hand, there were considerable genetic variations present for days to maturity although the temperature did not vary so much.

The primary yield components of mungbean are seeds per plant, pods per plant, seeds per pod and seed weight; yield of mungbean being the product of these components (Phoelman, 1991). In our study, yield significantly related more to seeds per plant than 100 -seed weight. The seeds per plant related more closely to pods per plant. The pods per plant and seeds per plant significantly related to all the yield contributing characters (Table 5). Similar results were also reported in other studies (Singh and Singh, 1973; Rathnaswamy et al., 1978; Satyan et al., 1986). Whereas other reports (Parida and Singh, 1984; Khan, 1985) indicate that there is significant relationship between all the yield contributing characters and yield. Analyzing the reports on yield and yield components, Phoelman (1991) concluded that pods per plant had stronger association with yield as compared with other yield components. The pods per plant also correlates with plant height and number of branches per plant. In this study, plant height and number of branches per plant were associated significantly with yield through pod production (Table 5). Therefore, if we want more number of seeds per plant for higher yield, we have to have more number of pods per plant. This can be made possible by having tall plants with more number of branches. Similar views were also expressed by several authors (Malhotra et al., 1974; Boomikumaran and Rathinam, 1981; Satyan et al., 1986).

Harvest index which is an indication of the partitioning of dry matter between grain and other above ground plant organs significantly correlated with yield and pods per plant. Significant correlations among these parameters were also reported by Kuo et al., (1980), Malik et al., (1986), Rathnaswamy et al., (1986). Higher HI represents large physiological capacity (often called sink power or sink capacity) to mobilize photosynthate and translocate it to organs having economic value (Wallace et al., 1972). Therefore, we can say that yield improvement in mungbean can be made by selecting genotypes with higher pods per plant and higher HI.

In this paper, we have tried to characterize the genotypes and have found that large variations occur among genotypes for growth, yield and yield contributing characters. Some genotypes having too much foliage, produced many pods; but the yield performance was poor, while others despite of having small foliage had good performance. We also found that plants with higher HI and more number of pods per plant were necessary to obtain higher yield.

Although till now mungbean is not grown commercially in Japan, through analysis of climatic data in relation to growth and yield, it can be said that mungbean can be successfully grown during the summer in the West-Southern area of Japan. The best growing time is from June to September when the mean air temperature remains above $20^{\circ} \mathrm{C}$. 


\section{REFERENCES}

Aggarwal, V. D. and J. M. Phoelman 1977 Effects of photoperiod and temperature on flowering in mungbean (Vigna yadiata (L.) Wilczek). Euphytica, 26: 207-219

Boomikumaran, P. and M. Rathinam 1981 Correlation and path coefficient analysis in green gram, vigna yadiata (L.) Wilczek. Madras Agric. J., 68: 643-647

Francisco, P. B. Jr. and K. Maeda 1989a Agro-physiological studies on the yield performance of mungbean (Vigna radiata (L.) Wilczek) I. Cultivaral differences in earliness in flowering and their relationships with growth and seed yield. Japan Jour. Crop Sci., 58: 704-711

Francisco, P. B. Jr. and K. Maeda 1989b Agro-physiological studies on the yield performance of mungbean (Vigna yadiata (L.) Wilczek). II. Cultivaral differences in dry matter production, partitioning, and yield components and their relationships with earliness in flowering. Japan Jour. Crop Sci., 58: 712-719

Hamid, A., F. Kubota, W. Agata and M. Morokuma 1990 Photosynthesis, transpiration, dry matter accumulation and yield performance of mungbean plant in response to water stress. $J$. Fac.Agr. Kyushu Univ., 35: 81-92

Imrie, B. C., D. W. Drake, I. H. De Lacy and D. E. Byth 1981 Analysis of genotypic and environmental variation in International Mungbean Trials. Euphytica, 30: 301-311

Imrie, B. C. and S. Shanmugasundaram 1987 Source of variation in International mungbean Trials. Field Crops Res., 16: 197-208

Khan, I. A. 1985 Correlation and path coefficient analysis of yield components in mungbean (Phasoelus auyeus Roxb.). Botanical Bulletin Academia Sinica., 26: 13-20

Kuo, C. G., F. H. Hsu., J. S. Tsay and H. G. Park 1980 Variation in specific leaf weight and RuDPCase activity in mungbean. Can. J. Plant Sci., 60: 1059-1062

Malik, B. A., M. Tahir, S. A. Hussain and A. H. Chowdhury 1986 Identification of physiologically efficient genotypes in mungbean. Pakistan J. Agyic. Res. 7:41-43.

Malhotra, V. V., S. Singh and K. B. Singh 1974 Yield components in greengram (Phaseolus aureus Roxb.). Identification of physiologically efficient genotypes in mungbean. Indian J. Agric. Sci., 44: 136-141

Parida, D. and D. P. Singh 1984 Association, heritability and genetic advance in the $F_{2}$ generation of wide and varietal crosses of green gram. Madras Agric. J., 71: 351-356

Phoelman, J. M. 1991 Genetics of quantitative characters. In "The Mungbean", Westview Press, Bouldar, Colorado, U.S.A., pp. 195-222

Rathnaswamy, R., M. Thangaraj, A. S. Shanmugam and S. R. S. Rangasawamy 1986 Characters limiting productivity in Vigna yadiata (L.) Wilczek. Madras Agyic. J., 73: 433-438

Rathanaswamy, R., S. Krishnaswamy., S. Iyemperumal., and P. V. Marappan 1978 Estimates of variability, correlation coefficients, and path coefficients analysis in early maturing greengram (Vigna yadiata (L.) Wilczek). Madras Agyic. J., 65: 188- 190

Satyan, B. A., K. S. Prakash and A. R. G. Ranganatha 1986 Yield structure analysis in mungbean. Indian J. G enet., 46: 558-562

Singh, T. P. and K. B. Singh 1973 Association of grain yield and its components in segregating populations of greengram. Indian J. Genet., 33: 112-117

Trung, B. C. and S. Yoshida 1982 A comment on the varietal differences of production of mungbean and its grain properties. Soil Sci. Plant Nutr., 28: 413-417

Trung, B. C. and S. Yoshida 1984 Influence of time of sowing on the grain productivity of mungbean (Raipur loc. var., India). Japan J.Trop. Agy., 28: 224-229

Wallace, D. H., J. L. Ozbun and H. M. Munger 1972 Physiological genetics of crop yield. Advan. Agyon., 24: 97-146 